\title{
Review
}

\section{Liberalism for the twenty-first century: The skeptical radicalism of Judith Shklar}

\author{
Giunia Gatta \\ New York and Abingdon, Routledge, 2018, 164pp., ISBN: 978-0815383833
}

Contemporary Political Theory (2020) 19, S67-S70. https://doi.org/10.1057/s41296018-0268-6; published online 17 September 2018

'Shklar's work [is] the meeting and clashing of two polar forces. One, keen on the memory of violence, abuse and cruelty, pulls Shklar toward pessimism; the other, drawn to the great reformist projects of the Enlightenment, fosters an optimistic glance, full of trust in the possibility of making society better' (p. 91). This is how Giunia Gatta, in her insightful (re-)interpretation of Judith Shklar's thought, describes the work of the American political theorist. And it is indeed with pithy and perceptive characterisations like this that Gatta's book accomplishes three purposes. First, it provides an introduction to, and overview of, Shklar's complex and rather unsystematic thought. At the same time, however, the book offers much more: second, it sets forth a compelling and original interpretation of Shklar as a radical thinker, and of her distinctive liberalism as an agonistic and subaltern alternative to naïve and complacent accounts. And thirdly, Gatta demonstrates that Shklar's distinctive liberalism yields crucial insights for thinking through, and probably even addressing, the ethical and political problems of the twenty-first century.

Judith Nisse Shklar, born in 1928 in Riga (Latvia), was the first tenured woman in Harvard's government department. She also became the first female president of the American Political Science Association, wrote eleven books on the history of ideas and political theory, and influenced many prominent political theorists and scientists. Shklar, to be sure, was a rather unsystematic thinker. Nothing, in fact, could have been further from her ambitions than to contrive political or philosophical 'programmes' or 'blueprints'. But it is also true that a certain 'mood' permeates her oeuvre and makes her work stand out of the canon of political theory. Gatta's characterisation of Shklar's thought as the meeting point of two polar forces, as a work shaped simultaneously by optimism and pessimism, as a work born out of hope for a better future and despair in the face of past political and moral catastrophes, captures this 'mood' almost perfectly. And it demonstrates that there is, in fact, a strong link between Shklar's earlier work in the history of ideas,

(c) 2018 Springer Nature Limited. 1470-8914 Contemporary Political Theory Vol. 19, S1, S67-S70 
and her later works, which deal more concretely with political phenomena such as injustice and cruelty.

Shklar began to forge this link in her first book After Utopia: The Decline of Political Faith (1957), and Gatta rightly devotes considerable attention to this work. After Utopia represents an attempt to defend the philosophical spirit of the Enlightenment against critics such as the Romantics (and Romanticism's epigone, Existentialism) and the various philosophies of 'Christian fatalism'. These critics claimed that the dogmatism and the sterility of the Enlightenment ushered in the destructive forces of totalitarianism. Against these critics of modernity, Shklar emphasised 'radical optimism', 'anarchism' and 'intellectualism' as the Enlightenment's cardinal traits. Gatta, accordingly, dubs After Utopia an 'anti-anti Enlightenment polemic' (p. 54) and concludes that 'if ... there is a nostalgia for the Enlightenment in the pages of After Utopia, it is an active nostalgia, a longing for a lost radicalism' (p. 51). In her view, it was precisely the radical spirit of the Enlightenment that animated Shklar's defence against the 'philosophies of despair', a radical spirit that must be revived even - or especially - in the face of the horrors of the twentieth century. At the same time, however, Shklar was anxious to temper the exuberant optimism of the Enlightenment with a skeptical attitude towards naïve optimism in order to save, as it were, the ideals of the Enlightenment from itself. Gatta, in other words, convincingly presents After Utopia as the book that set the tone for, and even established the central orientation of, Shklar's later work: her 'skeptical radicalism'.

Throughout the book, Gatta portrays Shklar's 'skeptical radicalism' as the distinguishing feature of her vision of liberalism. The skeptical dimension of this liberalism expresses itself in what I would call a 'double-skepticism'. On the one hand, Shklar was skeptical of the despair and cynicism that had suffocated the progressive and radical spirit of the Enlightenment; on the other hand, she was also skeptical of the naïve belief - often by (fellow) liberals - that progress is inevitable and society always harmonious (p. 57). Shklar's liberalism, therefore, is not, as it has sometimes been interpreted, a liberalism without hope but, rather, a liberalism without illusions. Gatta's most decisive move, however, is that she unearths the radical elements of Shklar's liberalism and demonstrates that this radicalism is rooted in her skepticism: 'There was no laceration in Shklar... between skepticism and progressive politics. In fact, her skepticism is at the root of her progressive commitments, rather than in competition with them' (p. 3). By unearthing these progressive and radical elements, Gatta sheds new light on a distinct facet of Shklar's thought, one that has eluded most of her commentators. For while Shklar's most famous contribution to political theory - the 'liberalism of fear' - has often been misconstrued as inherently conservative, Gatta rejects the charge of conservatism and insists that 'Shklar's... ultimate goal seems to be to shake political theory from its conservative torpor' (p. 57). The liberalism of fear is 
therefore more accurately understood as what Gatta refers to as 'agonistic liberalism'.

This 'agonistic liberalism' is characterised by Shklar's subaltern identification with the victims, the downtrodden, with those who always find themselves 'on the losing side of the political and legal game' (p. 111). One goal of this agonistic liberalism, to be sure, is simply to defend these victims against cruelty; however, Shklar's famous slogan of 'putting cruelty first' also means to empower these individuals and to give them a 'voice'. Shklar's, therefore, is an agonistic liberalism because it seeks to give a voice to the voiceless by constantly opening up and maintaining spaces for agonistic struggle and contestation.

This characterisation of Shklar's liberalism as an agonistic liberalism that takes as its ultimate point of reference the fate of the powerless who are always in danger of falling into the grips of power, allows Gatta to demonstrate very concretely why and how Shklar's agonistic liberalism truly is 'a liberalism for the twenty-first century': it is a liberalism built around 'permanent minorities', around migrants and refugees and even around those on the losing side of the processes of globalisation who are seduced by the simplistic recipes of populists.

Rethinking Liberalism for the twenty-first century offers a compelling, original and fruitful interpretation of a still slightly underappreciated political theorist. Dispelling the impression of Shklar as a predominantly conservative thinker, Gatta demonstrates that her thinking combines conservative and radical elements: conservative because of its emphasis on creating institutions and laws to defend the downtrodden; radical because of its simultaneous insistence to empower them. Unfortunately, the brevity of the book (149 pages, including endnotes and bibliography) neither allows Gatta to fully develop this interpretation nor to pursue its implications further. Much more could have been said, for instance, about the curious interplay of conservative and radical elements in Shklar's work: Are they in a symbiotic relationship? Is there a tension between them? If yes, is it a constructive tension?

Furthermore, it would have been interesting to bring Shklar into dialogue with other agonistic thinkers. While Gatta, as did Shklar herself, tends to downplay the parallels between Shklar and Hannah Arendt, it is precisely the combination of conservative and radical (indeed, agonistic) elements that both thinkers share. A contemporary agonist with whom Shklar's agonistic liberalism could be brought into productive dialogue is James Tully, who shares her subaltern outlook and concern for 'permanent minorities'. Finally, such an engagement with agonistic thinkers might shed light on a blind-spot in Shklar's thought: Shklar repeatedly emphasises - and this, again, aligns her with the agonistic tradition - that plurality is not only a fact to be tolerated but a value to be cherished. Unfortunately, though, she never tells her readers why she believes in the normative value of plurality. Gatta, although she repeatedly refers to Shklar's endorsement of plurality (pp. 111, $117,146)$, also passes over this question. The point is, however, that while it is

(c) 2018 Springer Nature Limited. 1470-8914 Contemporary Political Theory $\quad$ Vol. 19, S1, S67-S70 $\quad$ S69 
rather obvious that plurality is a fact, it is by no means self-evident that and why plurality is - and ought to be regarded as - a value.

Gatta's book, then, is certainly not a definitive study of Shklar's thought. And as an introduction to Shklar's oeuvre, Andreas Hess' intellectual portrait of Shklar (2014) remains unsurpassed. However, its contribution - and a substantial one at that - is that it offers a perceptive interpretation of Shklar as an agonistic thinker whose realism and wariness of exuberant optimism were sharpened by her historical awareness and personal experiences as a refugee, but who retained, nonetheless, a 'grain of baseless optimism' (Shklar, 1957, p. 271), which pulled her towards the radicalism we find in agonistic visions of politics. As such, the text provides a valuable jumping-off point for further research into Shklar's 'agonistic liberalism' and its profound relevance for the political and moral problems of the twenty-first century.

\section{References}

Hess, A. (2014). The Political Theory of Judith N. Shklar: Exile from Exile. Basingstoke: Palgrave Macmillan.

Shklar, J. N. (1957). After Utopia: The Decline of Political Faith. Princeton, NJ: Prin ceton University Press.

Christof Royer

University of St Andrews, St Andrews, Scotland KY16 9AJ, UK

cr208@st-andrews.ac.uk 